\title{
DNA damage and necroptosis induced by peroxidase from proso millet in human colorectal cancer cells
}

\author{
Xiaodong Cui ${ }^{1 *}$, Zhongqi Cao ${ }^{1}$, Zhuanhua Wang ${ }^{1,2}$ \\ ${ }^{1}$ Key Laboratory of Chemical Biology and Molecular Engineering of Ministry of Education, Institute of Biotechnology, ${ }^{2}$ School of \\ Life Science, Shanxi University, Taiyuan 030006, China
}

*For correspondence: Email: cuixiaodong@sxu.edu.cn Tel: +86 5317011499

Sent for review: 25 February 2019

Revised accepted: 30 April 2019

\begin{abstract}
Purpose: To investigate the effects of cationic peroxidase from proso millet (PmPOD) on DNA damage and necroptosis in human colon cancer HCT116 and HT29 cells.

Methods: Cell necroptosis and cell cycle was stained using Annexin V-FITC and cell cycle kits, respectively, and evaluated by flow cytometry. Lipid raft on the membrane was disrupted by cholesterol depletion and the location of PMPOD observed by confocal microscopy. Comet assays were used to detect DNA damage, and different inhibitors were also used. Knockdown of p53 or ectopic p53 expression in HCT116 cells were transfected p53 siRNA and pCMV3-TP53-myc plasmid, and p53 expression analyzed by western blotting.

Results: Pre-treatment of HCT116 and HT29 cell lines with the specific necroptosis inhibitor Nec-1 prevented PmPOD-induced necroptosis, whereas the apoptosis inhibitor, z-VAD-fmk, had no effect. The entry of PmPOD is necessary for induction of DNA damage and necroptosis. Furthermore, PmPOD induced cell cycle arrest at S phase, as well as DNA DSBs in vivo, as reflected by numerous $y-H 2 A X$ foci in CRC cells. However, the tumor suppressor protein, p53, alleviated PmPOD-induced DNA damage and necroptosis.

Conclusions: These results demonstrate that PMPOD-induced DNA DSBs in CRC cells is the main cause of necroptosis, and that the tumor suppressor protein, p53, alleviates PmPOD-induced necroptosis by promoting p53-mediated repair pathways.
\end{abstract}

Keywords: Cationic peroxidase, Necroptosis, DNA double strand breaks, Tumor suppressor protein p53, $v-H 2 A X$

\begin{abstract}
This is an Open Access article that uses a fund-ing model which does not charge readers or their institutions for access and distributed under the terms of the Creative Commons Attribution License (http://creativecommons.org/licenses/by/4.0) and the Budapest Open Access Initiative (http://www.budapestopenaccessinitiative.org/read), which permit unrestricted use, distribution, and reproduction in any medium, provided the original work is properly credited.
\end{abstract}

Tropical Journal of Pharmaceutical Research is indexed by Science Citation Index (SciSearch), Scopus, International Pharmaceutical Abstract, Chemical Abstracts, Embase, Index Copernicus, EBSCO, African Index Medicus, JournalSeek, Journal Citation Reports/Science Edition, Directory of Open Access Journals (DOAJ), African Journal Online, Bioline International, Open-J-Gate and Pharmacy Abstracts

\section{INTRODUCTION}

Colorectal carcinoma $(\mathrm{CRC})$ is the $3^{\text {rd }}$ most common malignancy worldwide, and global burden of its incidence and mortality has shifted to the developing countries in recent years, most likely driven by adoption of western-style diets [1]. Western diets have a high proportion of red meat and highly processed foods, and are deficient in vegetables and dietary fiber. These defects increase the risk for CRC. On the other hand, a healthy diet consisting largely of vegetables, fruits and whole grains, with lower intake of red meat, over processed meat and sweets, is associated with a lower risk for CRC $[2,3]$. The health benefits associated with the 
regular consumption of whole grains are most likely linked to lowering of risk factors for metabolic disorders such as type 2 diabetes and cardiovascular diseases: these risk factors are insulin resistance, dyslipidemia, inflammation and oxidative stress [4].

Necroptosis is caspase-independent programmed cell death, which has several similar morphological features with non-regulatory necrosis. It is mainly controlled by RIPK1 and RIPK3, and executed by MLKL $[5,6]$. Cell death is the ultimate goal of all cancer therapies, but a subset of apoptosis-resistant cancer cells may evolve. These resistant cancer cells may still be sensitive to necroptosis inducers that act via pathways independent of the apoptosis program [5]. Accordingly, cancer therapy based on necroptosis has been proposed as a novel anticancer therapeutic strategy. Cancer cells may also evade necroptosis by down-regulating regulatory molecules or by acquiring functional mutations in them. Necroptosis appears to have evolved as an alternative safeguard for inducing cell death in the event of caspase inactivation whereupon the cells cannot be eradicated by apoptosis [6].

Proso millet (Panicum miliaceum L.) is an oldest grains still cultivated and consumed in many developing countries, especially in Asia [7]. It is a highly nutritious cereal rich in protein and phytochemical compounds [7]. Studies have shown that the cationic peroxidase, PmPOD isolated from this millet induces RIPK1- and RIPK3-dependent regulatory cell necrosis in HCT116 and HT29 cells [8]. Although the exact mechanism is yet to be identified, recent studies indicate that PmPOD damages DNA through hydrolytic cleavage in vitro. The study was designed to investigate the DNA damage and necroptosis caused by PmPOD in CRC cells, and the potential mechanistic role of the tumor suppressor protein $\mathrm{p} 53$.

\section{EXPERIMENTAL}

\section{Reagents}

Fetal bovine serum (FBS), streptomycin (CAS: 57-92-1), penicillin (CAS: 61-33-6), and trypsin (1:250) were purchased from Sijiqing Company (Hangzhou, China), while RPMI Medium 1640 Basic (1x) was product of Gibco (Grand Island, NY). Hoechst 33342, Necrostatin-1 (Nec-1), dimethyl sulfoxide (DMSO) and methyl- $\beta$ cyclodextrin (m $\beta C D$, CAS: 128446-36-6) were the products of SIGMA-ALDRICH (St Louis, MO, USA). Low melting agarose and $\beta$-tubulin antibody were products of BBI Life Sciences
(Shanghai, China); z-VAD-fmk (CAS: 187389-522) and BCA protein concentration assay kit were bought from Beyotime (Shanghai, China). The plasmids pCMV3-TP53-myc and pCMV3 were bought from Sino Biological (Beijing, China). The antibodies used and their sources (in brackets) were: anti-p-H2AX (Ser139) (Bioss, Beijing, China); anti-H2AX and anti-p53 (Proteintech Group, Chicago, USA). The secondary antibodies were from ZS-BIO (Beijing, China).

\section{Cell culture}

Human colorectal cancer cell lines (HCT116 and HT29) were gained from Chinese Center Type Culture Collection (CCTCC), and routinely cultured in $90 \mathrm{~mm}$ plastic tissue culture flask with RPMI Medium 1640 Basic containing $10 \%$ FBS, 100 units $/ \mathrm{mL}$ penicillin, and $100 \mu \mathrm{g} / \mathrm{mL}$ streptomycin. Two cells lines were cultured as described previously [8].

\section{Necroptosis analysis by flow cytometric}

The cell death was measured through apoptosis detection kit (C1062S, Beyotime, Shanghai, China) by flow cytometric (Becton Dickinson, Mountain View, CA). After exposure to PmPOD and/or necroptosis inhibitor $\mathrm{Nec}-1$ or apoptotic inhibitor z-VAD-fmk, the HCT116 and HT29 cells were reaped by centrifugation at $600 \mathrm{~g}$ for $10 \mathrm{~min}$ at $4^{\circ} \mathrm{C}$, and re-suspended cells were added to binding buffer $(195 \mu \mathrm{L})$ provided with the kit, followed by addition of Annexin V-FITC ( $5 \mu \mathrm{L}$ ) and of $\mathrm{PI}(10 \mu \mathrm{L})$, with thorough mixing. Thereafter, the cells were kept in incubator (25 ${ }^{\circ} \mathrm{C}$ ) for $20 \mathrm{~min}$ in the dark, washed thrice, and then analyzed using flow cytometer. This double staining technique was used to distinguish live cells (low level of fluorescence), early-stage apoptotic cells (Annexin $\left.{ }^{+} / \mathrm{PI}\right)$ and necrotic cells (Annexin ${ }^{-} / \mathrm{PI}^{+}$) from advanced-stage apoptotic cells $\left(\right.$ Annexin $\left.{ }^{+} / \mathrm{PI}^{+}\right)$.

\section{Cell cycle analysis}

The disruption of cell cycle was analyzed using cell cycle and apoptosis analysis kit (C1052, Beyotime, Shanghai, China) according to the manual. The HCT116 and HT29 cells were seeded in 6-well plates, respectively. The number of cells was adjusted by medium, and each at a cell density of $2 \times 10^{5}$ cells/well. The both of cells were reaped and fixed in ice-cold 70 $\%$ ethyl alcohol in phosphate-buffer saline (PBS) at $4{ }^{\circ} \mathrm{C}$ for $2 \mathrm{~h}$. The cells were centrifuged at 600 $\mathrm{g}$ for $10 \mathrm{~min}$, after washing twice with PBS, the cells were incubated with the PBS staining solution containing $\mathrm{PI}$ and RNase A for 30 min in incubator $\left(25^{\circ} \mathrm{C}\right)$ in the dark, and analyzed using 
flow cytometry. The cell cycle distribution of 10 000 cells was recorded and analyzed by FloMax software.

\section{Lipid raft disruption by cholesterol depletion}

To deplete cellular cholesterol and disrupt lipid rafts, HCT116 and HT29 cells were pretreated with $2 \mathrm{mM}$ methyl- $\beta$-cyclodextrin $(\mathrm{m} \beta \mathrm{CD})$ in RPMI-1640/5\% FBS in incubator at $37^{\circ} \mathrm{C}$ for $4 \mathrm{~h}$, followed by dealing with $50 \mu \mathrm{g} / \mathrm{mL}$ PmPOD for 2 h. The treated cells were then transferred on ice to terminate the reaction, and the inhibition of pinocytosis was observed by confocal microscopy.

\section{Western blotting}

The HCT116 and HT29 colon cancer cells treated with different concentration PmPOD or same concentration of for specific time, and then were washed trice with pre-cooling PBS, and lysed using RIPA lysis buffer (P0013B, Beyotime, Shanghai, China). The lysates were scraped from the plates and centrifuged at $12000 \mathrm{~g}$ at 4 ${ }^{\circ} \mathrm{C}$ for $15 \mathrm{~min}$ for removing cell debris. The equal amount protein samples $(20 \mu \mathrm{g})$ were resolved using $8-12 \%$ SDS-PAGE and then the gel was electrotransferred onto polyvinylidene difluoride (PVDF) blotting membranes $(0.45 \mu \mathrm{m}$, A10176144, Millipore, Billerica, USA) at 0.8 $\mathrm{mA} / \mathrm{cm}^{2}$ for $40 \mathrm{~min}$. The membranes were further blocked with blocking buffer (containing 5\% skimmed milk powder and in $0.05 \%$ Tween20PBS) in incubator $\left(25^{\circ} \mathrm{C}\right)$ for $1 \mathrm{~h}$, and then incubated with the suitable primary antibodies (for H2AX, yH2AX PmPOD, RIPK1, RIPK3, p53, or $\beta$-tubulin; diluted 1:1000 in blocking solution) and slowly agitated at $4{ }^{\circ} \mathrm{C}$ overnight. After washing thrice in TBST (Tris- $\mathrm{HCl}$-buffered saline and $0.05 \%$ Tween 20 ) for $10 \mathrm{~min}$ each, the membranes were kept together with HRPconjugated secondary antibody (diluted 1:10 000 in blocking buffer) in sealed hybrid bag for $1 \mathrm{~h}$ at room temperature $\left(20-25^{\circ} \mathrm{C}\right)$. After washing specific protein bands were visualized using western blotting substrate (Engreen, Beijing, China) in dark room. $\beta$-Tubulin and H2AX were used as the loading control.

\section{Neutral and alkaline comet assay}

Neutral comet assay was executed as previously report [9] on HCT116 and HT29 cells after incubating cells with PmPOD with or without necroptosis inhibitors (Nec-1 and GSK-872) and ROS scavengers (NSA, BHA, BHT and NAC). Briefly, the human colon cancer cells were harvested and re-suspended in low-melting-point agarose $\left(0.7 \%\right.$, R0801, Thermo Scientific $\left.{ }^{\mathrm{TM}}\right)$ at a cell density of $10^{5}$ cells $/ \mathrm{mL}$, and $100 \mu \mathrm{L}$ of each sample was seeded on comet slides pre-coated with $1 \%$ normal-melting-point agarose. Coverslips were placed over the slides and the agarose was allowed to gel on a cool plate at 4 ${ }^{\circ} \mathrm{C}$ for about $10 \mathrm{~min}$. The slides were then immersed in the lysing buffer ( $10 \mathrm{mM}$ Tris, $2.5 \mathrm{M}$ $\mathrm{NaCl}, 100 \mathrm{mM} \mathrm{Na}{ }_{2}$ EDTA, $10 \%$ DMSO and $1 \%$ Triton $\mathrm{X}-100, \mathrm{pH} 10$,$) in the dark at 4{ }^{\circ} \mathrm{C}$ for $2 \mathrm{~h}$, and washed for $10 \mathrm{~min}$ in TBE buffer $(0.445 \mathrm{M}$ Tris- $\mathrm{HCl}, 0.445 \mathrm{M}$ boric acid, and also containing $0.01 \mathrm{M} \mathrm{Na}_{2}$ EDTA). The slides were placed horizontally on an electrophoresis tray, which was filled with TBE solution, electrophoresed for $30 \mathrm{~min}$ at $21 \mathrm{~V}$, and thereafter washed in $0.9 \%$ $\mathrm{NaCl}$ for $2 \mathrm{~min}$. The slides were neutralized using $0.4 \mathrm{M}$ Tris- $\mathrm{HCl}(\mathrm{pH} 7.5)$, then the they were stained with $8.0 \mu \mathrm{gg} / \mathrm{mL}$ EB for $5 \mathrm{~min}$, and observed under a fluorescence microscope with an excitation wavelength of $360 \mathrm{~nm}$. The cell number of DNA comets and the percentage DNA content in the comet tail region were quantitatively measured using Kinetic Comet 4.0 software. Three independent assays and 30 cells were analyzed for each slide. For the alkaline comet assay, the slides were kept in a denaturing buffer $\left(0.3 \mathrm{M} \mathrm{NaOH}, 1 \mathrm{M} \mathrm{Na}_{2}\right.$ EDTA, $\mathrm{pH}>13)$ for $1 \mathrm{~h}$ at $4{ }^{\circ} \mathrm{C}$, and electrophoresed at $21 \mathrm{~V}$ for $30 \mathrm{~min}$. The slides were then neutralized in $0.4 \mathrm{M} \mathrm{Tris}-\mathrm{HCl}(\mathrm{pH} \mathrm{7.5)}$ for about $5 \mathrm{~min}$, followed by TBE for 2 min and finally dehydrated through an ethanol gradient of $60,75,90$, and $100 \%$ for 5 min at each concentration.

\section{Immunofluorescence}

For PmPOD and $\mathrm{y}-\mathrm{H} 2 \mathrm{AX}$ staining, HT29 and HCT116 cells were seeded on coverslips precoated with 6-well plate, fixed with $4 \%$ paraformaldehyde (PFA), and after rinsing twice with PBS, they were permeabilized in $1 \%$ Triton $X-100$ prepared in PBS for about $10 \mathrm{~min}$. The coverslips were incubated with $5 \%$ BSA for blocking non-specific antibody binding sites inside cells at $37^{\circ} \mathrm{C}$ for $30 \mathrm{~min}$. Then, the coverslips were incubated with anti-PmPOD, or anti-y-H2AX (Ser139) (Bioss, Beijing, China) antibodies diluted in blocking buffer at $4{ }^{\circ} \mathrm{C}$ overnight, washed thrice, and incubated with FITC-conjugated secondary antibodies. The nuclei were counterstained with Hoechst33342. The stained samples were examined under a laser scanning confocal microscope. The wash buffer used in every step was PBS.

\section{P53-siRNA and pCMV3-TP53-myc transfec- tion}

Negative control siRNA (siNC), RIPK1 siRNA, RIPK3 siRNA, or p53 siRNA (Sangon Biotech, 
Shanghai, China) was transfected into $85 \%$ confluent HCT116 cells or HT29 cells at a final concentration of 75 pM using TurboFect transfection reagent (ThermoFisher Scientific, Waltham, MA, USA). The knockdown efficiency was evaluated $24 \mathrm{~h}$ later by western blotting. Plasmid pCMV3-TP53-myc and control plasmid pCMV3 were also transfected into normal HCT116 cells at a final concentration of $2.5 \mu \mathrm{g}$, using the above protocol.

\section{Statistical analysis}

The distribution of all data sets was made using one-way analysis of variance (ANOVA) by using the SPSS13.0 software packages (SPSS, Inc., Chicago, IL, USA). All data are expressed as mean \pm standard deviation (mean $\pm S D, n=3$ ). $p<0.05$ and $p<0.01$ were considered to significant difference and distinctively significant difference.

\section{RESULTS}

PmPOD induced colon cancer cell
necroptosis

In a previous study, it was found that PmPOD time and dose dependently induced necroptosis in human colon cancer HCT116 and HT29 cells by ATP assay, and its $\mathrm{IC}_{50}$ values were $54.87 \pm$ 3.67 and $47.50 \pm 3.89 \mu \mathrm{g} / \mathrm{mL}$ for the HT29 and HCT116 cells, respectively [8]. As shown in Figure $1 A$ and $B, 50 \mu \mathrm{g} / \mathrm{mL}$ PmPOD significantly reduced the viability of $\mathrm{HCT} 116$ cells, with a marked aggrandize in the necrotic or late apoptotic cells, as featured by loss of membrane integrity which made for easy staining with $\mathrm{PI}$. After $24 \mathrm{~h}$ of treatment, the necrotic cells increased to $32.41 \%$ in HCT116 cells and 26.11 $\%$ in HT29 cells, when compared to 5.23 and $2.23 \%$ in the respective untreated controls. However, no significant increase was seen in the proportion of Annexin $\mathrm{V}^{+} / \mathrm{PI}$ (early apoptotic cells) following PmPOD treatment. In addition, reduction of cell viability triggered by $\mathrm{PmPOD}$ was not blocked by the apoptotic inhibitor z-VADfmk, which rather aggravated the toxic effects of PmPOD (Figures $2 \mathrm{~A}$ and $\mathrm{B}$ ). Following pretreatment with the necroptosis inhibitor Nec1(RIPK1 inhibitor, CAS: 4311-88-0), PmPODinduced cell death was significantly attenuated (Figures $2 \mathrm{~A}$ and $\mathrm{B}$ ). These finding are consistent with previous reports, indicate that PmPOD induced necroptosis in CRC cells [8].

\section{Cholesterol reduction inhibited PmPOD- induced cell death}

Incubation of HCT116 and HT29 cells with 2 mM

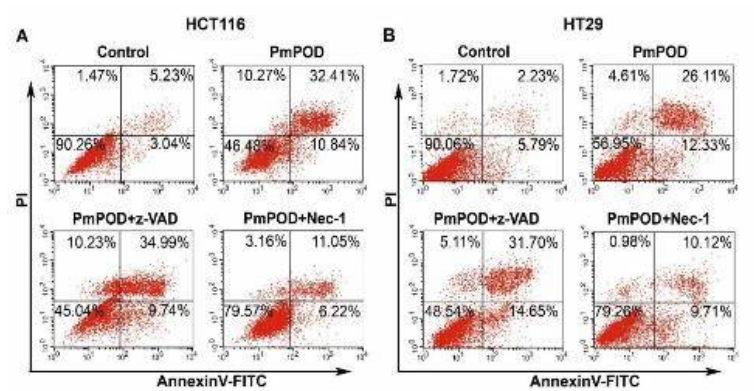

Figure 1: Association of PmPOD-induced CRC cell death with necroptosis. Annexin V/PI double staining results showing the percentage of Annexin $\mathrm{V}^{+} / \mathrm{PI}^{-}$(early apoptotic) and Annexin $\mathrm{V}^{-} / \mathrm{PI}^{+}$and $\mathrm{V}^{+} / \mathrm{PI}^{+}$(necrotic or advanced-stage apoptotic). HCT116 cells (A) and HT29 cells (B) after $24 \mathrm{~h}$ of incubation with $50 \mu \mathrm{g} / \mathrm{mL}$ PmPOD either alone or in combination with z-VAD-fmk or $\mathrm{Nec}-1$
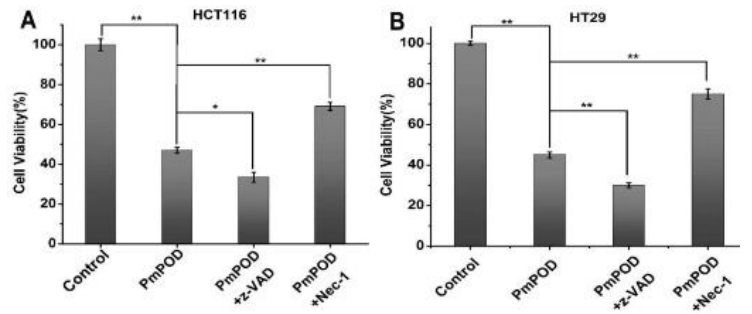

Figure 2: Association of PmPOD-induced CRC cell viability change with necroptosis. ATP assays showing percentage of viable HCT116 cells (A), and HT29 cells (B) after $24 \mathrm{~h}$

$m \beta C D$ for $4 \mathrm{~h}$ at $37^{\circ} \mathrm{C}$ led to reduction in the levels of total cellular cholesterol and disruption the structure of lipid raft. As shown in Figure $3 \mathrm{~A}$ and $B, P m P O D$ was mainly distributed in and around the nuclei in the untreated cells, while it was almost absent in the m $\beta C D$-treated cells. In addition, $m \beta C D$-induced lipid raft disruption in the PmPOD-treated cells significantly increased their viability (Figure $3 \mathrm{C}$ and $\mathrm{D}$ ).

The viability of HCT116 cells following treatment with $50 \mu \mathrm{g} / \mathrm{mL}$ PmPOD for 2 and $24 \mathrm{~h}$ were 89.12 and $61.1 \%$, respectively, while the corresponding viabilities in the HT29 cells under the same treatment for 2 and $24 \mathrm{~h}$ were 83.28 and $52.1 \%$, respectively. However, when cotreated with $\mathrm{m} \beta C D$, the viability values after 2 and $24 \mathrm{~h}$ increased to 95.01 and $87.34 \%$, respectively in HCT116 cells, and 95.9 and 86.2 $\%$, respectively in HT29 cells. These results indicate that cholesterol depletion inhibited PmPOD endocytosis in CRC cells, thereby increasing their viability.

\section{PmPOD induced cell cycle arrest at $S$ phase}

To determine the potential effect of PmPOD on the cell cycle dynamics of HCT116 and HT29 


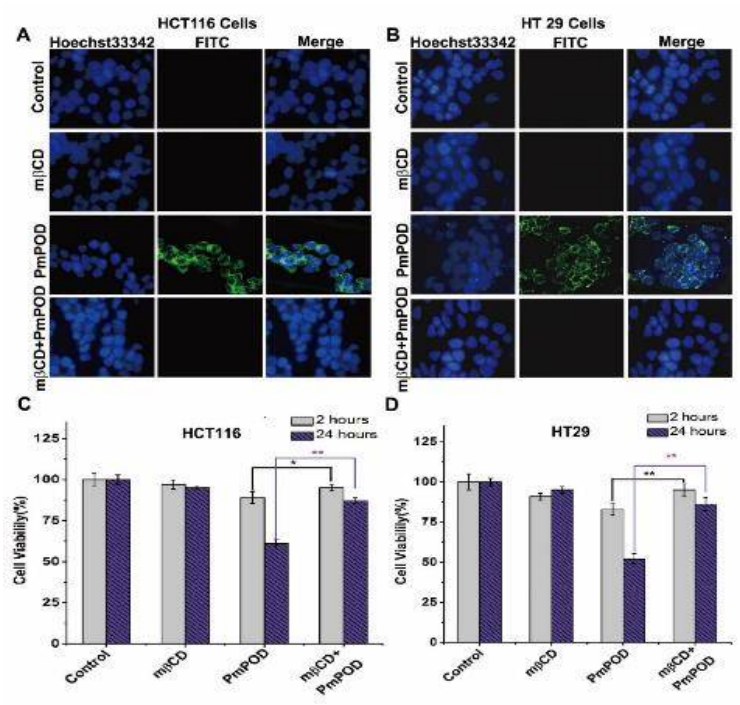

Figure 3: Cholesterol-dependence of endocytosis and cytotoxicity of PmPOD. Representative immunofluorescence images showing uptake of PmPOD in the contrastive and $2 \mathrm{mM} m \beta C D$-pro-treated cells ( $A$ and $\mathrm{B})$; and ATP assay showing percentage of viable control and $m \beta C D$-treated cells after 2 and $24 \mathrm{~h}$ of PmPOD treatment $(C$ and $D)$

cells, both cell lines were treated with PmPOD and then PI staining was used to evaluate cell cycle distribution. As shown in Figure 3, PmPOD resulted in concentration-dependent accumulation of cells at the $S$ phase, with concomitant reduce in the $\mathrm{G}_{0} / \mathrm{G}_{1}$ phase cells. Treatment of HCT116 cells with 10,25 and $50 \mu \mathrm{g} / \mathrm{mL}$ PmPOD upregulated the proportion of cells at the $S$ phase to $31.86,36.87$ and $38.76 \%$, respectively, compared to $30.16 \%$ in the untreated controls. The treatments also resulted in decreases in $\mathrm{G}_{0} / \mathrm{G}_{1}$ phase cells from 49.54 to $45.71,40.56$ and $38.56 \%$ respectively (Figure $4 A$ and $B$ ).

The number of HT29 cells at S phase increased from 29.41 to $35.66,38.76$ and $39.36 \%$ following treatment with 10,25 and $50 \mu \mathrm{g} / \mathrm{mL}$ PmPOD, respectively (Figure $4 \mathrm{C}$ and $\mathrm{D}$ ). The cells at the "sub-G1 area" represent apoptotic cells in the sample. In the analysis of PmPOD-treated cells, the number of cells in the sub-G1 phase was small and negligible. In HCT116 cells treated with 10, 25 and $50 \mu \mathrm{g} / \mathrm{mL}$ PmPOD, the percentages of sub-G1 phase cells were 0.10 , 0.12 and $0.59 \%$, respectively, while that of the untreated control group was $0.08 \%$. In contrast, in HT29 cells treated with 10,25 and $50 \mu \mathrm{g} / \mathrm{mL}$ PmPOD, the percentages of sub-G1 phase cells were $0.12,0.54$ and $0.08 \%$, respectively, while that of the untreated control group was $0.06 \%$. These consequences suggest that the PmPODmediated reduction in CRC cell viability is associated with cycle arrest at the $\mathrm{S}$ phase.

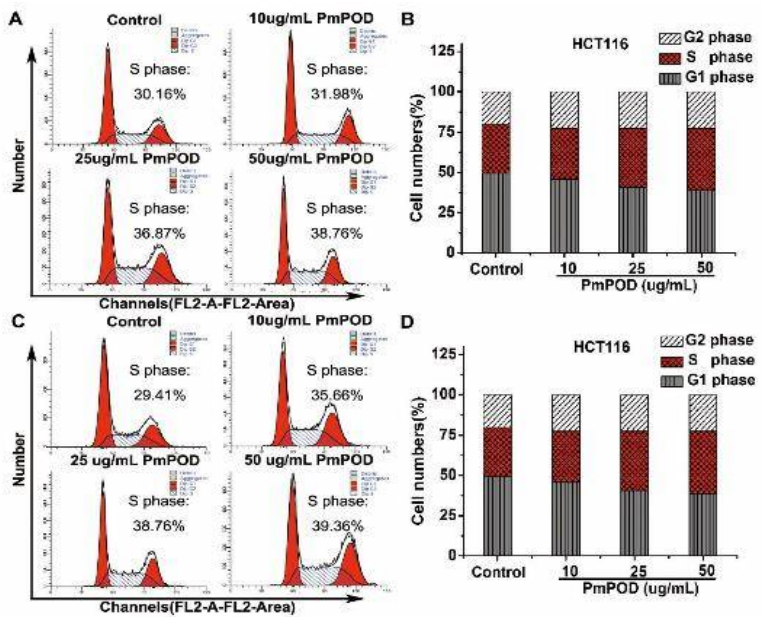

Figure 4: PmPOD arrested cell cycle in CRC cells at $S$ phase. Distribution of different stages of cell cycle was detected in human colon cancer HCT116 (A) and HT29 (C) cells using flow cytometry. The cells were kept with 10, 25 and $50 \mu \mathrm{g} / \mathrm{mL}$ PmPOD for $24 \mathrm{~h}$, and stained with propidium iodide $(\mathrm{PI})$. Percentage of HCT116 (B) and HT29 (D) cells in the different cell cycle phases

\section{DNA DSBs induced by PmPOD in CRC cells}

Alkaline and neutral comet assays are sensitive and rapid technique for evaluate various forms of DNA damage and DNA DSBs, respectively. As is shown in Figure $5 \mathrm{~A}$ and $\mathrm{B}$, majority of the HCT116 and HT29 cells treated with 25 or 50 $\mu \mathrm{g} / \mathrm{mL}$ PmPOD for $24 \mathrm{~h}$ had long comet tails in both assays, in contrast to the untreated controls, indicating that PmPOD induced overall DNA damage as well as DSBs. In addition, quantification of the alkaline and neutral comet assays revealed that PmPOD treatment not only increased the number of cells with DNA damage, but also the DNA content within the tails (Figure $5 \mathrm{C}$ and $\mathrm{D})$. Furthermore, the DNA content in the comet tails of HT29 cells were higher than that of the HCT 116 cells ( $37 \%$ vs $25 \%$ ).

\section{PmPOD induced formation of $\mathrm{Y}-\mathrm{H} 2 \mathrm{AX}$ foci}

Rapid phosphorylation of $\mathrm{H} 2 \mathrm{AX}$ at Ser-139 of the minor histone $\mathrm{H} 2 \mathrm{~A}$ variant to produce $\mathrm{Y}-\mathrm{H} 2 \mathrm{AX}$, is an early cellular response to DSBs, which is making it a suitable marker of DNA DSBs [10]. The number of $\mathrm{Y}-\mathrm{H} 2 \mathrm{AX}$ foci per nucleus increased significantly in both HCT116 and HT29 cells incubated for $6 \mathrm{~h}$ with 25 or $50 \mu \mathrm{g} / \mathrm{mL}$ PmPOD (Figure 6A). Interestingly, most of the foci were clustered around the nuclei rather than within them in the HT29 cells (Figure 6 B). These in situ immunofluorescence findings were validated by western blotting of the total cellular proteins (Figure $6 \mathrm{C}$ ). Furthermore, $\mathrm{Y}-\mathrm{H} 2 \mathrm{AX}$ levels increased significantly in a time-dependent 
manner following $25 \mu \mathrm{g} / \mathrm{mL}$ PmPOD treatment for 6,12 and $24 \mathrm{~h}$ (Figure $6 \mathrm{D}$ ). In contrast, a sharp increase in $\mathrm{y}-\mathrm{H} 2 \mathrm{AX}$ was seen after $12 \mathrm{~h}$ of incubation with $50 \mu \mathrm{g} / \mathrm{mL}$ PmPOD, but no further increase occurred at $24 \mathrm{~h}$ (Figure $6 \mathrm{D}$ ). These results indicate that the generation of DNA DSBs is a committed step that precedes PmPODinduced necroptosis of CRC cells.

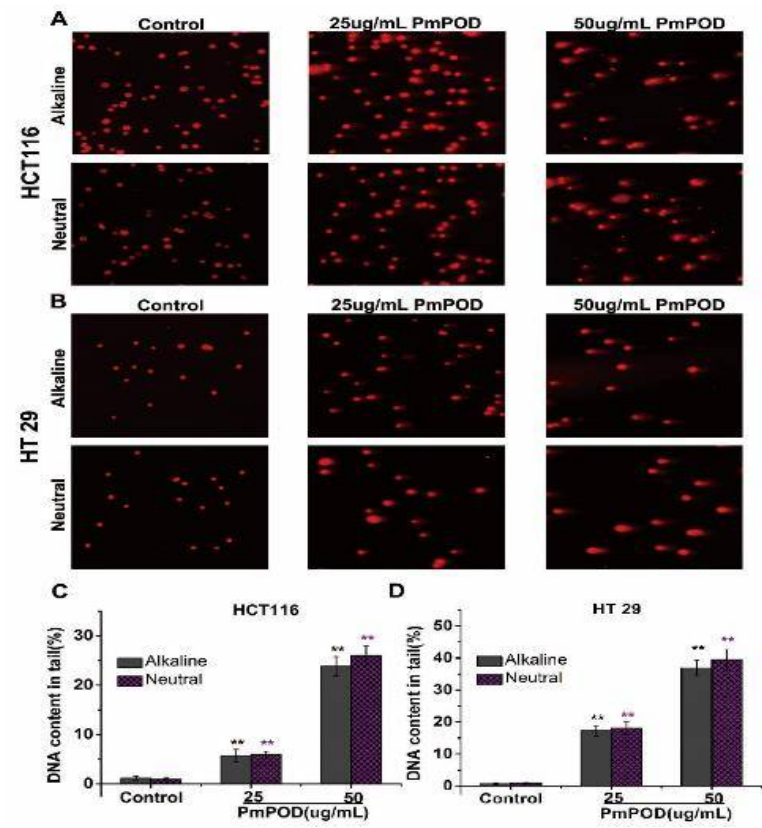

Figure 5: PmPOD triggered DNA Damage in CRC cells. Representative fluorescence images of HCT116 and HT29 cells after alkaline and neutral comet assays (A \& B). Quantification of DNA content in the comet tails of HCT116 (C) and HT29 (D) cells
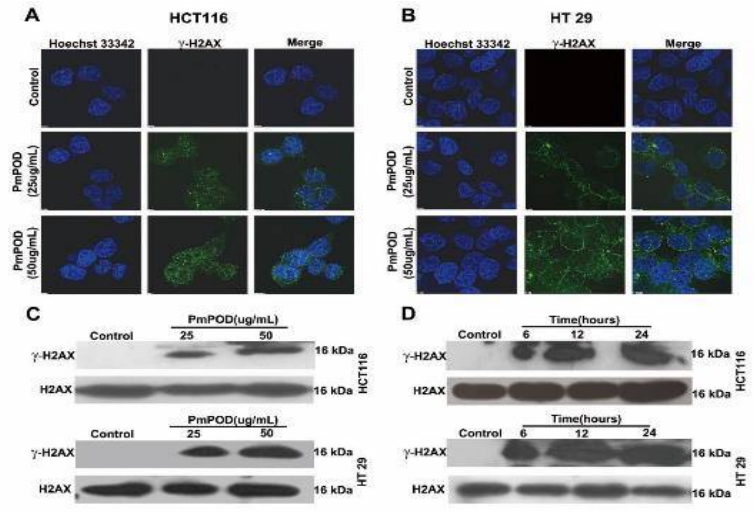

Figure 6: PmPOD treatment induced formation of YH2AX foci in CRC cells. Representative immunofluorescence images of PmPOD-treated HCT116 (A) and HT29 (B) cells showing $\mathrm{Y}-\mathrm{H} 2 \mathrm{AX}$ foci; immunoblot showing $\mathrm{Y}-\mathrm{H} 2 \mathrm{AX}$ expression levels in colon cancer cells treated with different concentrations of PmPOD (C); immunoblot showing $\mathrm{Y}-\mathrm{H} 2 \mathrm{AX}$ levels in PmPOD-treated CRC cells in a time dependent manner (D)
PmPOD-induced DNA damage and necroptosis were associated with $p 53$ expression

To determine the potential role of $\mathrm{p} 53$ expression in the cellular response to PmPOD, p53 expression was silenced in HCT116 cells before PmPOD treatment (Figure 7 B). The p53 knockdown markedly altered nuclear morphology and aggravated DNA damage in the PmPODtreated cells (Figure $7 \mathrm{~A}$ ), and significantly enhanced PmPOD-induced necroptosis (Figure 7 C). In addition, ectopic p53 expression via the pCMV3-TP53-myc plasmid (Figure 7 D) significantly reduced the DNA damage triggered by PmPOD (Figure $7 \mathrm{~A}$ ), and de-sensitized the HCT116 cells to PmPOD-induced cell death (Figure $7 \mathrm{E}$ ). It was also found that PmPOD induced elevation in ROS in colon cancer HCT116 and HT29 cells, and that RIPK1 and RIPK3 conduced to PmPOD-induced ROS overproduction (Figure 8). Both of HCT116 and HT29 cells treated with PmPOD $(50 \mu \mathrm{g} / \mathrm{mL})$ had longer comet tails. The appearance of the comet tails in cells was not significantly suppressed in the presence of necroptosis inhibitors (Nec-1, GSK-872, and NSA), nor was it significantly prevented in the presence of ROS scavengers (BHA, BHT or NAC) (Figure 9). These findings indicate that the DNA DSBs of PmPOD on the CRC cells is dependent on p53 expression.

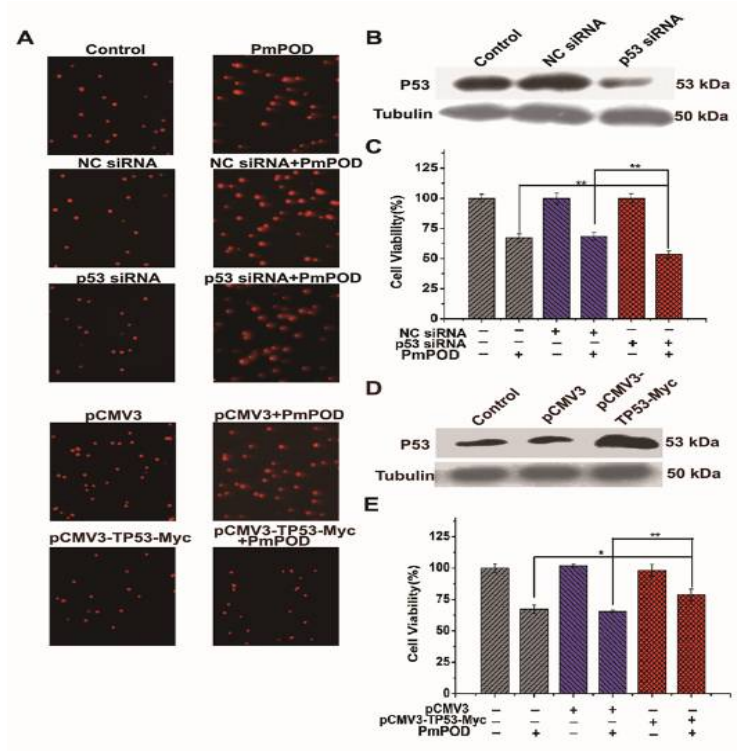

Figure 7: Effect of $p 53$ on repair of DNA DSBs and necroptosis induced by PmPOD in CRC cells. Representative fluorescence images of control, p53knockdown and p53-overexpressing HCT116 cells after neutral comet assay (A). Immunoblot showing p53 expression levels after p53 knockdown or overexpression ( $B$ and $D$ ). Percentage of viable HCT116 cells with p53 knockdown or overexpression after PmPOD treatment ( $\mathrm{C}$ and $\mathrm{E})$ 


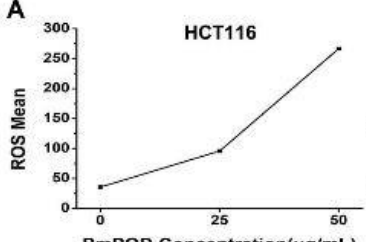

B

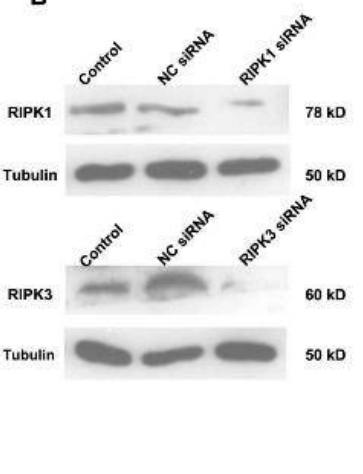

CmPOD Concentration(ug/mL)

C * Control NC siRNA+PmPOD RIP1 siRNA+PmPOD RIP3 siRNA+PmPOD

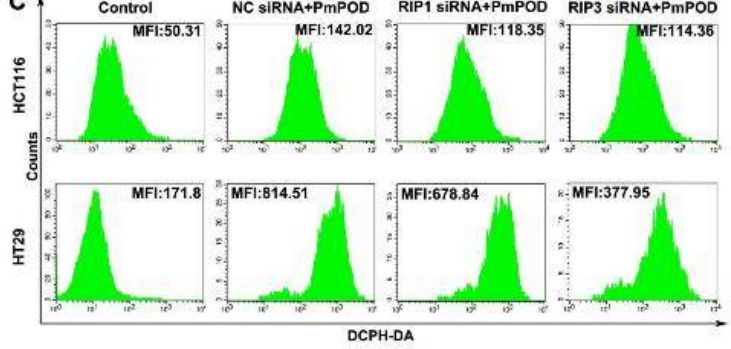

Figure 8: RIPK1 and RIPK3 regulated PmPODinduced production of intracellular ROS. A: The ROS in HCT116 and HT29 cells were stained with the DCFH-DA probe after incubation with PmPOD for 24 h. B: Immunoblot showing RIPK1 and RIPK3 expression levels after RIPK1 and RIPK3 knockdown in HCT116 cells. C: The fluorescence density analysis of ROS induced by PmPOD after siRIPK1 or siRIPK3 treatment
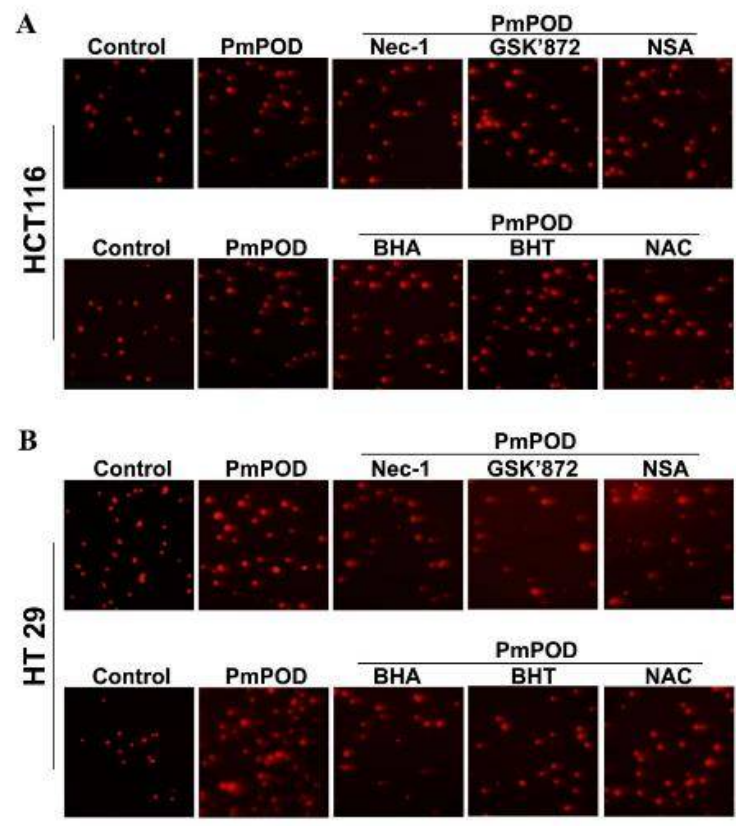

Figure 9: Effect of necroptosis inhibitors and ROS scavengers on PmPOD-induced DNA DSBs in HCT116 and HT29 cells. Representative images of HCT116 and HT29 cells under fluorescence microscope (A for HCT116; B for HT29 cells; x10)

\section{DISCUSSION}

This study has demonstrated that PmPODtriggered DNA DSBs in human colon cancer HCT116 and HT29 cells are the main cause of necroptosis. DNA DSBs are potentially lethal DNA lesion, which may arise spontaneously during DNA replication or consequences of external disadvantage, such as ionizing radiation (IR), oxidative stress and chemotherapeutic drugs $[11,12]$. DNA DSBs can be lethal if not repaired or if it is mis-repaired. Therefore, DSBs sensors induce cell cycle arrest at the $S$ phase, in which allow the cells to undergo DNA repair. It was found that PmPOD induced cell cycle arrest at the $S$ phase in $C R C$ cells.

Cells undergo DNA replication during $S$ phase, and since accurate replication is necessary to prevent genetic aberrations which can lead to apoptosis or other pathological conditions, this stage of the cell cycle are crucial for detecting and repairing any DNA damage. When the replication fork arrives at the damaged site, protein kinase is activated [13], which in turn triggers ATM- and ATR-mediated DNA damage response [11]. Both pathways activate the cellcycle-checkpoints, which either allow the cells to repair the damage or prevent the proliferation of the damaged cells by inducing senescence, or in case of extensive damage, may also lead to apoptotic cell death.

An important step in ATM- and ATR-dependent signaling is the phosphorylation of H2AX at Ser139 to produce $\mathrm{Y}-\mathrm{H} 2 \mathrm{AX}$, which accumulates at the DSBs sites and is thus a suitable and sensitive molecular maker of DNA damage[12]. In addition to recruiting DNA repair proteins, $y$ $\mathrm{H} 2 \mathrm{AX}$ also recruits the apoptosis inducing factor (AIF) from the mitochondria to form DNAdegrading complex during necroptosis. Therefore, production DNA DSBs may be a crucial cause leading to cells undergoing necroptosis [12,14].

The p53 is not only tumor-suppressing gene, but also a stress-responsive transcription factor that can activate different target genes in response to diverse stimuli, including oxidative stress, genotoxic damage and hypoxia [15]. Therefore, it is also known as "the guardian of the genome" for its role in preserving the stability of the genome. Mutation p53 or loss of normal p53 function is strongly associated with an increased susceptibility to various types of cancer [16]. P53 protects cells against malignant transformation, and is deleted or mutated in approximately $50 \%$ of human cancers [13]. 
In the present study, ectopic expression of p53 significantly alleviated the PmPOD-induced DNA damage in human colon cancer cells. The DNA damage pathway stabilizes p53, which then transcriptionally activates a number of genes regulating cell cycle arrest or apoptosis [17], and hence cell fate [18]. Amongst the p53-target genes, p21 induces cell cycle arrest at $G_{1}$ and $S$ phase, which provids time for DNA repair and promotes cell survival [18] [19]. In contrast, Bax, PUMA and Noxa are crucial for p53-dependent apoptosis [20-22]. Recent studies have revealed that inhibition of intracellular ROS (induced by shikonin) with scavenger suppressed DNA DSBs caused by $\mathrm{H}_{2} \mathrm{O}_{2}$, suggesting that ROS also play a very important role in regulation of DNA DSBs[12, 23]. Basis on experimental results of this study, it can be hypothesized that p53 plays an important role in repairing PmPOD-induced DNA damage and necroptosis. This may be due to the selective activation of p53-target genes. However, this needs to be further validated.

Fluid-phase endocytosis or pinocytosis, which is a non-receptor-mediated endocytosis, refers to the uptake of macromolecules from the extracellular fluid into cytoplasm by membranebound endocytotic vesicles [24]. m $\beta C D$ suppresses fluid-phase endocytosis by removing cholesterol from the plasma membrane [25]. Horseradish peroxidase (HRP) is a representative of class III heme peroxidases [26]. Cerebral endothelial cells take up HRP by pinocytosis, a non-receptor-mediated endocytosis, and the protein is stable inside the cell for at least several hours [27].

Transient expression of HRP in mammalian cells does not produce serious toxicity $[28,29]$. However, sustained expression of HRP in cells brings about morphological changes and death, although the underlying mechanism is still unknown [30]. Being a cationic peroxidase, PmPOD-induced tumor cell necroptosis is a function of the mode of entry of PmPOD into the cells. To determine the mechanism of PmPOD internalization, its endocytosis in $\mathrm{m} \beta \mathrm{CD}$-treated and contrastive cells were tracked via immunofluorescence. In this study, it was found that PmPOD was taken up by fluid-phase endocytosis, since its intracellular uptake was disrupted by m $\beta C D$-mediated cholesterol depletion, which also inhibited cell necroptosis. These results indicate that PmPOD entry is necessary for induction of DNA damage and necroptosis.

\section{CONCLUSION}

This paper demonstrates that DNA DSBs induced by PmPOD in CRC cells is the main cause of necroptosis, and that the tumor suppressor protein p53 alleviates PmPODinduced necroptosis by promoting cell survival through p53-mediated repair pathways.

\section{DECLARATIONS}

\section{Acknowledgement}

This work was supported by Natural Sciences Foundation of China (no. 31300653), the Scientific and Technological Committee of Shanxi Province (no. 201801D121192) and Scientific and Technological Innovation Programs of Higher Education Institutions in Shanxi (no. 201802020).

\section{Conflict of interest}

No conflict of interest is associated with this work.

\section{Contribution of authors}

All work was done by the author named in this article and the authors accept all liability resulting from claims which relate to this article and its contents. Xiaodong Cui and Zhuanhua Wang designed the study and interpreted the results. Zhongqi Cao collected data and drafted the manuscript. Zhongqi Cao performed the experiments.

\section{Open Access}

This is an Open Access article that uses a funding model which does not charge readers or their institutions for access and distributed under the terms of the Creative Commons Attribution License (http://creativecommons.org/licenses/by/ 4.0) and the Budapest Open Access Initiative (http://www.budapestopenaccessinitiative.org/rea d), which permit unrestricted use, distribution, and reproduction in any medium, provided the original work is properly credited.

\section{REFERENCES}

1. Arnold M, Sierra MS, Laversanne M, Soerjomataram I, Jemal A, Bray F. Global patterns and trends in colorectal cancer incidence and mortality. Gut 2017; 66(4): 683-691.

2. Randi G, Edefonti V, Ferraroni M, La Vecchia C, Decarli A. Dietary patterns and the risk of colorectal cancer and adenomas. Nutr Rev 2010; 68(7): 389-408.

3. Magalhães $B$, Peleteiro B, Lunet $N$. Dietary patterns and colorectal cancer: systematic review and meta-analysis. Eur J Cancer Prev 2012; 21(1): 15-23. 
4. Wirström T, Hilding A, Gu HF, Östenson CG, Björklund A. Consumption of whole grain reduces risk of deteriorating glucose tolerance, including progression to prediabetes. Am J Clin Nutr 2013; 97(1): 179-187.

5. Su Z, Yang Z, Xie L, DeWitt JP, Chen Y. Cancer therapy in the necroptosis era. Cell Death Differ 2016; 23(5): 748-756.

6. Christofferson DE, Yuan J. Necroptosis as an alternative form of programmed cell death. Curr Opin Cell Biol 2010; 22(2): 263-268.

7. Zhang L, Liu R, Niu W. Phytochemical and antiproliferative activity of proso millet. PLoS One 2014; 9(8): 104058.

8. Cui $X$, Wang $R$, Wang $Z$. Cationic peroxidase from proso millet induces human colon cancer cell necroptosis by regulating autocrine TNF-alpha and RIPK3 demethylation. Food Funct 2018; 9(3): 1878-1888.

9. Dong $H, X u D$, Hu L, Li L, Song E, Song Y. Evaluation of $\mathrm{N}$-acetyl-cysteine against tetrachlorobenzoquinoneinduced genotoxicity and oxidative stress in HepG2 cells. Food and Chemical Toxicology 2014; 64: 291-297.

10. Mah LJ, El-Osta A, Karagiannis TC. yH2AX: a sensitive molecular marker of DNA damage and repair. Leukemia 2010; 24(4): 679-686.

11. O'Driscoll M, Jeggo PA. The role of double-strand break repair - insights from human genetics. Nat Rev Genet 2006; 7(1): 45-54

12. Zhou Z, Lu B, Wang C, Wang Z, Luo T, Piao M, Meng F, Chi G, Luo Y, Ge P. RIP1 and RIP3 contribute to shikonin-induced DNA double-strand breaks in glioma cells via increase of intracellular reactive oxygen species. Cancer Lett 2017; 390: 77-90.

13. Branzei $D$, Foiani $M$. The DNA damage response during DNA replication. Curr Opin Cell Biol 2005; 17(6): 568575.

14. Artus $C$, Boujrad $H$, Bouharrour A, Brunelle $M N$, Hoos $S$, Yuste VJ, Lenormand $P$, Rousselle JC, Namane A, England $P$, et al. AIF promotes chromatinolysis and caspase-independent programmed necrosis by interacting with histone H2AX. EMBO J 2010; 29(9): 1585-1599.

15. Vousden KH, Lane DP. p53 in health and disease. Nat Rev Mol Cell Biol 2007; 8(4): 275-283.

16. Halazonetis TD, Gorgoulis VG, Bartek J. An oncogeneinduced DNA damage model for cancer development. Science 2008; 319(5868): 1352-1355.

17. Aylon $Y$, Oren M. Living with p53, dying of p53. Cell 2007; 130(4): 597-600.
18. Vousden $\mathrm{KH}$. Outcomes of p53 activation - spoilt for choice. J Cell Sci 2006; 119(24): 5015-5020.

19. Abbas T, Dutta A. p21 in cancer: intricate networks and multiple activities. Nat Rev Cancer 2009; 9(6): 400-414.

20. Miyashita T, Reed JC. Tumor-Suppressor P53 Is a Direct Transcriptional Activator of the Human Bax Gene. Cell 1995; 80(2): 293-299.

21. Yu J, Zhang L, Hwang PM, Kinzler KW, Vogelstein B. PUMA Induces the Rapid Apoptosis of Colorectal Cancer Cells. Molecular Cell 2001; 7(3): 673-682.

22. Morsi RZ, Hage-Sleiman R, Kobeissy H, Dbaibo G. Noxa: Role in Cancer Pathogenesis and Treatment. Curr Cancer Drug Targets 2018; 18(10): 914-928.

23. Ren G, Luo W, Sun W, Niu $Y$, Ma DL, Leung $C H$, Wang $Y$, Lu JJ, Chen $X$. Psoralidin induced reactive oxygen species (ROS)-dependent DNA damage and protective autophagy mediated by NOX4 in breast cancer cells. Phytomedicine 2016; 23(9): 939-947.

24. Fekri F, Delos Santos RC, Karshafian R, Antonescu CN. Ultrasound Microbubble Treatment Enhances ClathrinMediated Endocytosis and Fluid-Phase Uptake through Distinct Mechanisms. PLoS One 2016; 11(6): 0156754.

25. Ashbourne Excoffon KJ, Moninger T, Zabner J. The coxsackie $B$ virus and adenovirus receptor resides in a distinct membrane microdomain. J Virol 2003; 77(4): 2559-2567.

26. Grigorenko VG, Andreeva IP, Rubtsova MY, Egorov AM. Recombinant horseradish peroxidase: production and analytical applications. Biochemistry (Mosc) 2015; 80(4): 408-416.

27. Noble LJ, Kalinyak JE, Pitts LH, Hall JJ. Fluid-phase endocytosis of horseradish peroxidase by cerebral endothelial cells in primary culture: characterization and kinetic analysis. J Neurosci Res 1994; 38(6): 654-663.

28. Schikorski T, Young SM Jr, Hu Y. Horseradish peroxidase cDNA as a marker for electron microscopy in neurons. J Neurosci Methods 2007; 165(2): 210-215.

29. Connolly CN, Futter CE, Gibson A, Hopkins CR, Cutler DF. Transport into and out of the Golgi-Complex Studied by Transfecting Cells with Cdnas Encoding HorseradishPeroxidase. J Cell Biol 1994; 127(3): 641-652.

30. Johannes L, Miyagawa-Yamaguchi A, Kotani N, Honke K. Expressed Glycosylphosphatidylinositol-Anchored Horseradish Peroxidase Identifies Co-Clustering Molecules in Individual Lipid Raft Domains. PLoS One 2014; 9(3): 93054. 